University of New Hampshire

University of New Hampshire Scholars' Repository

Faculty Publications

3-15-1999

\title{
An estimate of the uptake of atmospheric methyl bromide by agricultural soils
}

\author{
Ruth K. Varner \\ University of New Hampshire, Durham, ruth.varner@unh.edu \\ Patrick M. Crill \\ Stockholm University \\ Robert W. Talbot \\ University of New Hampshire, Durham \\ Joanne H. Shorter \\ Aerodyne Research, Inc.
}

Follow this and additional works at: https://scholars.unh.edu/faculty_pubs

\section{Comments}

This is an article published by AGU in Geophysical Research Letters in 1999, available online: https://dx.doi.org/

10.1029/1999GL900071

\section{Recommended Citation}

Varner, R.K., P.M. Crill, R.W. Talbot and J.H. Shorter (1999), An estimate of the uptake of atmospheric methyl bromide by agricultural soils, Geophys. Res. Lett., 26, 727-730.

This Article is brought to you for free and open access by University of New Hampshire Scholars' Repository. It has been accepted for inclusion in Faculty Publications by an authorized administrator of University of New Hampshire Scholars' Repository. For more information, please contact Scholarly.Communication@unh.edu. 


\title{
An estimate of the uptake of atmospheric methyl bromide by agricultural soils
}

\author{
Ruth K. Varner, Patrick M. Crill, Robert W. Talbot \\ Complex Systems Research Center, University of New Hampshire, Durham \\ Joanne H. Shorter \\ Center for Atmospheric and Environmental Chemistry, Aerodyne Research, Inc., Billerica, Massachusetts
}

\begin{abstract}
Published estimates of removal of atmospheric methyl bromide $\left(\mathrm{CH}_{3} \mathrm{Br}\right)$ by agricultural soils are $2.7 \mathrm{Gg} \mathrm{yr}^{-1}\left(\mathrm{Gg}=10^{9} \mathrm{~g}\right)$ [Shorter et al., 1995] and $65.8 \mathrm{Gg} \mathrm{yr}^{-1}$ [Serça et al., 1998]. The Serça et al. estimate, if correct, would suggest that the current value for total removal of atmospheric $\mathrm{CH}_{3} \mathrm{Br}$ by all sinks of $206 \mathrm{Gg} \mathrm{yr}^{-1}$ (based on Shorter et al., 1995) would be $30 \%$ too low. We have calculated a new rate of global agricultural soil uptake of atmospheric $\mathrm{CH}_{3} \mathrm{Br}$ from a larger sampling of cultivated soils collected from 40 sites located in the United States, Costa Rica, and Germany. First order reaction rates were measured during static laboratory incubations. These data were combined with uptake measurements we reported earlier based on field and laboratory experiments [Shorter et al. 1995]. Tropical $\left(10.2^{\circ}-10.4^{\circ} \mathrm{N}\right)$ and northern $\left(45^{\circ}-61^{\circ} \mathrm{N}\right)$ soils averaged lower reaction rate constants than temperate soils probably due to differing physical and chemical characteristics as well as microbial populations. Our revised global estimate for the uptake of ambient $\mathrm{CH}_{3} \mathrm{Br}$ by cultivated soils is $7.47 \pm 0.63 \mathrm{Gg} \mathrm{yr}^{-1}$, almost three times the value that we reported in 1995 .
\end{abstract}

\section{Introduction}

Methyl bromide $\left(\mathrm{CH}_{3} \mathrm{Br}\right)$, a widely utılized soil and structural fumigant, is a potential source of stratospheric ozone depleting bromine [Wofsy et al. 1975; McElroy et al. 1986]. Bromine has been determined to destroy ozone 50 times more efficiently than chlorine [Yung et al. 1980; Solomon et al. 1992; WMO, 1992; Mano et al. 1994]. Due to this potentıal detrimental effect and $\mathrm{CH}_{3} \mathrm{Br}$ ' s relatively large ozone depletion potential (ODP), the reduction and eventual cessation of the industrial production and use of $\mathrm{CH}_{3} \mathrm{Br}$ was scheduled for 2001 by the 1995 Montreal Protocol [UNEP, 1995].

The current understanding of the tropospheric budget for $\mathrm{CH}_{3} \mathrm{Br}$ implies a significant discrepancy between sinks and sources [Yvon-Lewis and Butler, 1997]. Sources equaling approximately $137 \mathrm{Gg} / \mathrm{yr}$ of atmospheric $\mathrm{CH}_{3} \mathrm{Br}$ include biological production and release from the ocean [Khalil et al. 1993; Yvon-Lewis and Butler, 1997], emission from fumigation of cultivated land, structures, and perishables [Yates et al. 1996, 1997], combustion of leaded gasoline [Penkett et al. 1995; Baker et al. 1998], biomass burning [Blake et al. 1993; Cicerone et al. 1994; Mano and Andreae, 1994], and production from terrestrial higher plants [Gan et al., 1998].

The principal sinks of atmospheric $\mathrm{CH}_{3} \mathrm{Br}$ include loss to the ocean [Butler et al. 1994; Lobert et al. 1995; Yvon and Butler,

Copyright 1999 by the American Geophysical Union.

Paper number 1999GL900071. 0094-8276/99/1999GL900071\$05.00
1996], reaction with OH [Penkett et al. 1995; Prinn et al. 1995], uptake by soils [Shorter et al. 1995; Serça et al. 1998], and possibly uptake by green plants [Jeffers and Wolfe, 1997; Jeffers et al. 1998]. The sinks total approximately $206 \mathrm{Gg} / \mathrm{yr}$ [Yvon-Lewis and Butler, 1997] with the soll sink contributing $21 \%$ [Shorter et al. 1995].

The Shorter et al. [1995] report was our first attempt to estimate the global uptake of ambient $\mathrm{CH}_{3} \mathrm{Br}$ by soils. Our research involved measuring the uptake of $\mathrm{CH}_{3} \mathrm{Br}$ by selected soils from a New Hampshire forest, cornfield, and grass covered site, a Costa Rican forest, and a Canadian boreal forest. We determined that the uptake was microbially mediated by the use of sterilization and various antibiotics [Hines et al. 1998]. We then extrapolated these measurements to obtain a global soll sink estimate. Recently, Serça et al. [1998] reported flux measurements with a new estimate of uptake by all soils that is more than twice the one we obtained. The major disparity between these two estimates is the agricultural uptake values. Uptake by agricultural soils made up approximately seven percent of our total estimate whereas it makes up approximately 70 percent of Serça et al. [1998]. In both cases, uptake estimates were based on a limited number of laboratory and/or field experiments utilizing only agricultural soils from New Hampshire or Colorado. To get a more accurate estimate of the uptake of $\mathrm{CH}_{3} \mathrm{Br}$ due to agricultural soil, we expanded our measurements to include cultivated sites from across the United States, Costa Rica, and Germany.

\section{Experimental Procedure}

Since it is not economically or logistically feasible to conduct field experiments at locations around the world, laboratory incubations of soils collected around the world were completed. We determined that laboratory incubations of soils yield similar results as field flux measurements. The work discussed in this paper is the result of these laboratory incubations. Soil samples from $0-5 \mathrm{~cm}$ and $10-15 \mathrm{~cm}$ depths were collected from 40 sites including an eastwest transect of agricultural soils across the mid-northern United States, agricultural and pasture sites in Costa Rica, and cultivated sites in Germany. The sampling sites consisted of pastures, fallow fields, and agricultural fields. The pastures and fallow fields were mostly bare ground with scattered grass cover while the planted fields varied from a bare surface to crop cover. The crop types included corn, alfalfa, palmheart, tomatoes, soybeans and various grains. Soil classifications for each sampling site were obtained either during sample collection or from United State Geological Survey soil maps. Soils were stored in doubled plastic bags at $0^{\circ} \mathrm{C}$ and were incubated within 4 weeks of sampling. Experiments completed to determine loss of activity in soils during 6 months of 
storage after collection revealed that there was a loss of less than one third the original activity over the time period.

Laboratory incubations entailed placing 5 to 20 grams of soil into twelve, $200 \mathrm{ml}$ glass vials which were sealed and suspended in a $25^{\circ} \mathrm{C}$ water bath. The vials were injected with $3 \mathrm{ml}$ of 270 parts per billıon by volume (ppbv) $\mathrm{CH}_{3} \mathrm{Br}$ to obtain an initial head space mixing ratio of approximately $4 \mathrm{ppbv}$. The vial head space was evacuated at specified time intervals with Ultra High Purity Nitrogen (UHP $\mathrm{N}_{2}$ ) into a sample loop immersed in a dry ice/isopropanol bath. The sample loop contained a plug of Poropak $\mathrm{Q}$ (Alltech) packing and quartz wool to allow the head space sample to be immobilized on the plug. The sample loop was immersed in boiling water and connected to an electron capture detector gas chromatograph (8A GC-ECD, Shimadzu). The oxygen $\left(\mathrm{O}_{2}\right)$ doped $\mathrm{N}_{2}$ carrier gas flowed through the sample loop carrying the volatilized head space sample into the pre-column, through the analytical column and then to the detector. Details of the sampling and analytical procedures can be found in Kerwin et al. [1996].

The resulting peak areas were compared to daily standard curves and concentrations calculated. The daily standard curves included replicates of the following 5 volumes of standard: 1.0, 0.5, 0.25, 0.1 and $0.05 \mathrm{ml}$ of $270 \mathrm{ppbv} \mathrm{CH}_{3} \mathrm{Br}$. The average $\mathrm{r}^{2}$ of the linear regression fit of peak area versus nmoles of $\mathrm{CH}_{3} \mathrm{Br}$ for the 6 month period of sampling was $\mathbf{0 . 9 9 9 8}$. Replicate head space samples for each of the six time segments were completed. A reaction rate constant, $\mathrm{k}$, was determined as the slope of the regression fit of the natural $\log$ of nmoles of $\mathrm{CH}_{3} \mathrm{Br}$ versus time. This $\mathrm{k}$, in min $^{-1}$, was then divided by the grams of dry soil (ds) in the vial resulting in a measured reaction rate constant with the units of $\min ^{-1} \mathrm{~g}^{-1} \mathrm{ds}^{-}$

The soil $\mathrm{pH}$, water content, and organic matter were measured for all of the incubated agricultural soils. $\mathrm{pH}$ was measured using a combination electrode and $10 \mathrm{~g}$ of air dried soil in a $0.01 \mathrm{M} \mathrm{CaCl}_{2}$ solution. Soil moisture content was determined in a drying oven at $70^{\circ} \mathrm{C}$ for 24 hours. Soil organic matter content was measured by ashing 3 to $7 \mathrm{~g}$ of oven dried soil in a muffle furnace at $450^{\circ} \mathrm{C}$ for 24 hours. Details of the measurement procedures can be found in Carter, [1993].

\section{Results}

The average reaction rate constants and standard errors are presented in Table 1 according to approximate latitudinal location and depth of sampling site. The temperate zone $\left(40^{\circ}-43^{\circ} \mathrm{N}\right)$ had the most rapid uptake of $\mathrm{CH}_{3} \mathrm{Br}$ while the northern and tropical zones were approximately $10 \%$ less active. Surface soils were on average more active than deeper soils by approximately $50 \%$. In a few isolated cases the deeper soils were more active.

On average, the surface soils tend to be only slightly drier than the deeper soils in the tropical samples, whereas in the temperate
Table 2. Estimate of Global Ambient $\mathrm{CH}_{3} \mathrm{Br}$ by Agricultural Soils with Different Land Area Estimates

\begin{tabular}{llc}
\hline \multicolumn{1}{c}{ Cultivated Land References } & $\begin{array}{c}\text { Land Area } \\
\times 10^{6} \mathrm{~km}^{2}\end{array}$ & $\begin{array}{c}\text { Uptake Estimate } \\
\mathrm{Gg} \mathrm{yr}^{-1}\end{array}$ \\
\hline Matthews, 1983 & 17.56 & $8.17 \pm 0.69$ \\
Born, 1990 & 14 & $6.52 \pm 0.55$ \\
Guenther et al., 1995 & 19.4 & $9.03 \pm 0.76$ \\
DeFries et al., 1995 & 13.28 & $6.18 \pm 0.52$ \\
Average & & $7.47 \pm 0.63$ \\
\hline
\end{tabular}

None of the references separated out the cultivated areas by latitude except Guenther $e t$ al., 1995 which only specified warm and cold regions. Therefore, the uptake estimate calculations were completed with an average reaction rate constant from all the soil incubations.

and northern samples the moisture content at the two depths were almost equal. The organic matter content varied more with depth than the moisture content. The greatest organic matter content was measured in the surface layer, and it was generally higher than that in the deeper layer with about $7 \%$ less in the $10-15 \mathrm{~cm}$ tropical soils, $26 \%$ less in the $10-15 \mathrm{~cm}$ temperate soils, and about $23 \%$ less in the $10-15 \mathrm{~cm}$ northern soils. As expected, $\mathrm{pH}$ varied considerably between climatic zones from an average of 7.28 in the northern areas to 4.97 in the tropics.

\section{Estimate of the global uptake by agricultural soils}

The flux of tropospheric $\mathrm{CH}_{3} \mathrm{Br}$ into the soil was calculated from the measured reaction rate constants obtained in the laboratory incubation experiments. By taking the same approach as Bender and Conrad, [1993]:

$$
\begin{gathered}
\text { Flux }=\mathrm{k} * \mathrm{~V} * \mathrm{~d} * \text { b.d. } *\left[\mathrm{CH}_{3} \mathrm{Br}\right] \\
* 1440 \mathrm{~min} / \text { day } * 94.94 \mathrm{~g} \mathrm{CH} \mathrm{Br} / \mathrm{mol} * 10^{4} \mathrm{~cm}^{2} / \mathrm{m}^{2}
\end{gathered}
$$

where Flux is in $\mathrm{g} \mathrm{m}^{-2} \mathrm{day}^{-1}, \mathrm{k}$ is in $\min ^{-1} \mathrm{~g}_{\mathrm{ds}}^{-1}$ (average of all soil incubations performed), $V$ is the vial head space of $200 \mathrm{~cm}^{3}$ for the laboratory experiments, $\mathbf{d}$ is the depth of uptake in $\mathrm{cm}$ (assumed to be $1 \mathrm{~cm}$ because the uptake is the fastest in the surface soils), b.d. is the bulk density of the soil in $\mathrm{g} \mathrm{cm}^{-3}\left(1.5 \mathrm{~g} \mathrm{~cm}^{-3}\right.$, average of those measured), and $\left[\mathrm{CH}_{3} \mathrm{Br}\right]$ is $4.5 \times 10^{-16}$ moles $\mathrm{cm}^{-3}$ (ambient $\mathrm{CH}_{3} \mathrm{Br}$ equal to $11.1 \mathrm{pptv}$ for the Northern Hemisphere where most of the agricultural land is located [Lobert et al. 1995]).

To estimate the global sink of tropospheric $\mathrm{CH}_{3} \mathrm{Br}$ to agricultural soils we extrapolated cultivated land areal extent using global estimates [Matthews, 1983; Born, 1990; Guenther et al. 1995; DeFries et al. 1995]. Flux, in $\mathrm{g} \mathrm{m}^{-2} \mathrm{day}^{-1}$, was multiplied by the areal extent of cultivated land and by the number of days in the growing season ( 240 days for agricultural soils). It is assumed that

Table 1. Summary of Laboratory Incubations

\begin{tabular}{lcccccc}
\hline $\begin{array}{c}\text { Climatic Regime } \\
\text { (Latitude) }\end{array}$ & $\begin{array}{c}\text { Depth, } \\
\mathrm{cm}\end{array}$ & $\begin{array}{c}\text { Reaction rate constant } \\
\mathbf{k}, \mathrm{min}^{-1} \mathrm{~g}_{\mathrm{ds}}^{-1}\end{array}$ & $\begin{array}{c}\text { Moisture } \\
\text { Content, \% }\end{array}$ & $\begin{array}{c}\text { Organic } \\
\text { Matter, \% }\end{array}$ & $p \mathrm{H}$ & $n$ \\
\hline Tropical & $0-5$ & $0.0092 \pm 0.0038$ & $61.4 \pm 6.2$ & $22.4 \pm 3.5$ & $4.97 \pm 0.08$ & 3 \\
$\left(10.2^{\circ}-10.4^{\circ} \mathrm{N}\right)$ & $10-15$ & $0.0057 \pm 0.0005$ & $63.6 \pm 5.3$ & $20.8 \pm 2.0$ & $4.59 \pm 0.17$ & 4 \\
& & & & & & \\
Temperate & $0-5$ & $0.011 \pm 0.0018$ & $19.1 \pm 2.2$ & $5.68 \pm 0.6$ & $6.33 \pm 0.10$ & 25 \\
$\left(40^{\circ}-43^{\circ} \mathrm{N}\right)$ & $10-15$ & $0.0058 \pm 0.0008$ & $18.5 \pm 1.7$ & $4.17 \pm 0.4$ & $629 \pm 0.12$ & 25 \\
& $0-5$ & $0.0095 \pm 0.0042$ & $24.9 \pm 7.9$ & $9.88 \pm 4.5$ & $7.28 \pm 0.57$ & 8 \\
Northern & $10-15$ & $0.0067 \pm 0.0033$ & $24.8 \pm 7.1$ & $7.6 \pm 2.8$ & $7.39 \pm 0.56$ & 10 \\
$\left(45^{\circ}-61^{\circ} \mathrm{N}\right)$ & & & & & & \\
\hline
\end{tabular}

Estimated errors are standard error of the mean for the samples. 
since the uptake is a microbial process, this activity is insignificant when the soil is frozen. Table 2 contains the results of these calculations.

\section{Discussion}

We find a global uptake of ambient $\mathrm{CH}_{3} \mathrm{Br}$ by agricultural soils of $7.47 \pm 0.63 \mathrm{Gg} \mathrm{yr}^{-1}$. This is a far improved estimate than our previous one for the agricultural soil sink because we sampled a wide variety of soil types with a range of soil properties from many crop types across a broad latitudinal extent. Our estimate in 1995 was $2.7 \mathrm{Gg} \mathrm{yr}^{-1}$, almost three times smaller than our new estimate [Shorter et al. 1995]. This difference is most likely attributed to the greatly increased data base of soil uptake rate measurements.

Many studies have examined $\mathrm{CH}_{3} \mathrm{Br}$ consumption in soil when it is added at fumigant levels [Oremland et al. 1994; Miller et al. 1998]. Some studies have related uptake dynamics to environmental factors such as temperature, moisture content, and/or organic matter content [Gan et al. 1994; Rice et al. 1996]. The soil uptake of ambient $\mathrm{CH}_{3} \mathrm{Br}$ appears to be microbially mediated [Hines et al. 1998]. The greatest uptake rates were measured in temperate zone soils even though they had the lowest average moisture and organic matter content. This may be because all the soil incubations were performed at $25^{\circ} \mathrm{C}$ which is closer to the average ambient temperature for the temperate soils than it is for tropical and northern soils. There should be an optimum moisture and organic matter content where the microbes responsible for uptake reside, but because of the variation of soil properties the individual effects of these factors are difficult to isolate.

A temperature manipulation study was performed on two agricultural soil samples from Iowa and Illinois, USA. The soils were incubated at $5,15,25,35$ and $45^{\circ} \mathrm{C}$ and the reaction rate constants determined. The results reveal a specific response to temperature that is typical of a microbial population (Figure 1) [Madigan et al. 1997].

The only other published research on the uptake of ambient $\mathrm{CH}_{3} \mathrm{Br}$ by soils gives an estimate for cultivated soils of $65.8 \pm 29.2$ $\mathrm{Gg} \mathrm{yr}^{-1}$ [Serça et al. 1998]. Their observed deposition velocities for $\mathrm{CH}_{3} \mathrm{Br}$ were measured at an agricultural field site in Colorado $(n=7)$. The discrepancy between these estımates are probably due to differences in measurement technique, sampling location and flux calculation method. Their field measurements were completed in a recently plowed agricultural field that had not received rainfall since plowing. Both studies reveal that microbially mediated uptake is common but that sampling in one location, as we did in 1995, will give an estimate that is restricted to sites with similar physical characteristics.

\section{Conclusions}

The uptake of ambient $\mathrm{CH}_{3} \mathrm{Br}$ by agricultural soils is a ubiquitous process that varies with location. The rate of uptake is dependent on soil physical properties as well as sampling location with specific controls hard to isolate. Further work must be undertaken to determine the physical, chemical and biological controls on uptake by agricultural soils.

Our estimate of the global uptake rate for agricultural soils is almost three times what we reported in 1995 . This is because we have broadened our database to include agricultural soils from 40 new sites from across the U.S., Costa Rica, and Germany. By sampling at so many sites we believe that this is a more representative estimate for uptake by agricultural soils than our previous one. Though this new estimate is significant, it does not significantly affect the lifetime of $\mathrm{CH}_{3} \mathrm{Br}$ in the atmosphere.

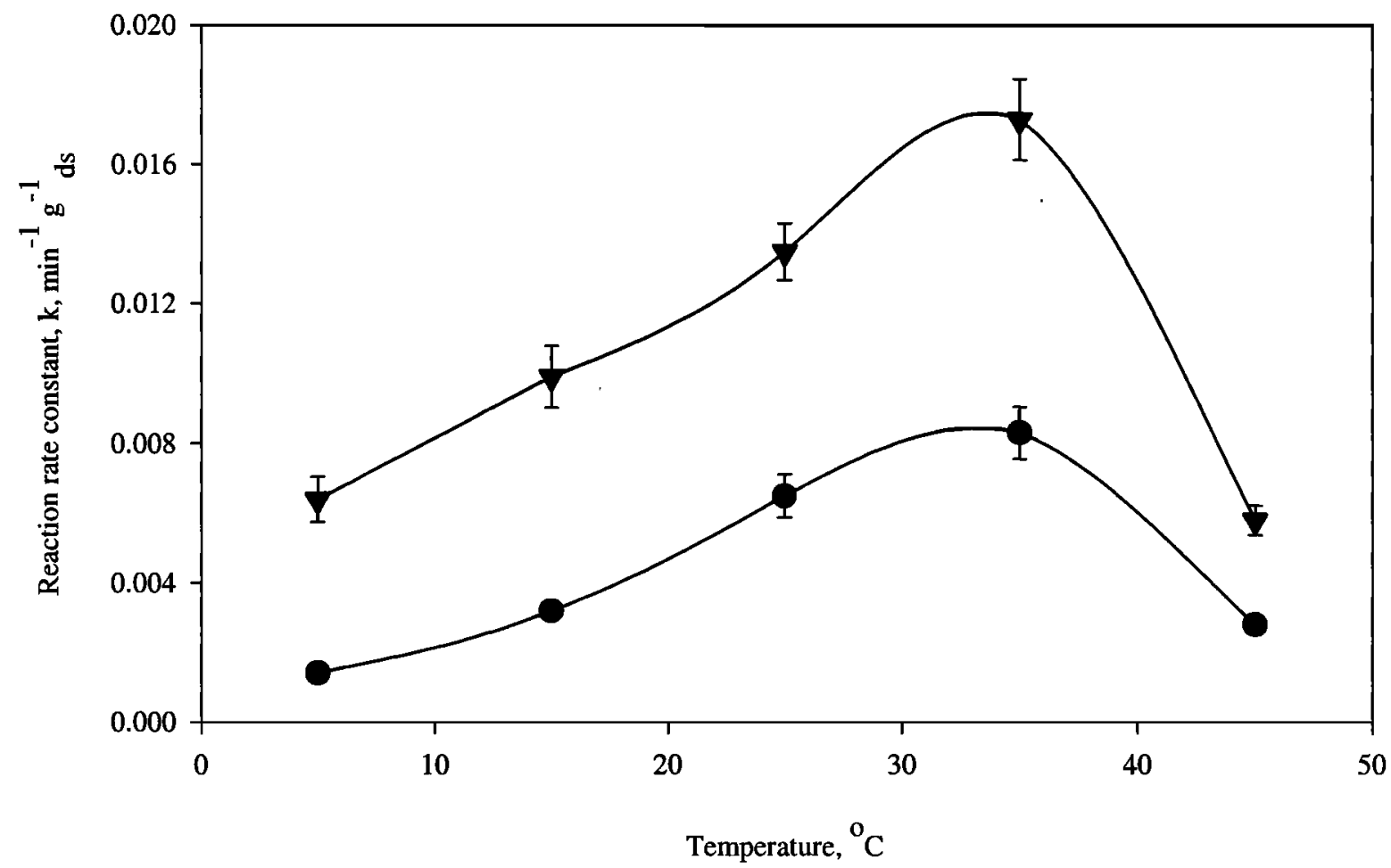

Figure 1. Temperature manipulation experiment utilizing two Mid-western United States agricultural soils. Illinois soil, $\nabla$ - Iowa soil. (Each point is the linear regression fit of 10 to 12 points of the $\ln$ of nmoles of $\mathrm{CH}_{3} \mathrm{Br}$ measured during soil incubations versus time normalized to grams of dry soil. The error bars are the standard error of the slope of the linear regression also normalized to grams of dry soil.) 
Acknowledgments. We would like to thank all of those who were helpful in collecting soil samples for this project: Cindy and Andrew Mosedale, Mark Hines, Antje Weitz, Lorin Bohne, Steve Frolking, Jill Bubier, Ed Veldkamp, and William Z. DeMello. We would also like to thank the National Science Foundation for financial support of this project.

\section{References}

Baker, J.M., C.E. Reeves, S.A. Penkett, L.M. Cardenas, and P.D. Nightıngale, An estimate of the global emissions of methyl bromide from automobile exhausts, Geophys. Res. Lett., 25 (13), 2405-2408, 1998.

Bender, M., and R. Conrad, Kinetics of methane oxidation in oxic soils, Chemosphere, 26 (1-4), 687-696, 1993.

Blake, D.R., B. Sive, M. Zondlo, and F.S. Rowland, Estimated methyl bromide emissions from biomass burning, EOS Trans. AGU, 74 (43), 134, 1993.

Born, M., H. Dorr, and I. Levin, Methane consumption in aerated soils of the temperate zone, Tellus, 42B, 2-8, 1990.

Butler, J.H., The potential role of the ocean in regulatıng atmospheric CH3Br, Geophys. Res. Lett., 2 I (3), 185-188, 1994.

Butler, J.H, and J.M. Rodrigues, Methyl bromide in the atmosphere in The Methyl Bromide Issue, John Wiley and Sons, Ltd., London, 1996.

Carter, M.R.,ed., Soil Sampling and Methods of Analysis, 823 pp., Lewis Publishers, Boca Raton, 1993.

Cicerone, R.J., Fires, atmosperic chemistry, and the ozone layer, Science, $263,1243-1244,1994$.

Cicerone, R.J., L.E. Heidt, and W.H. Pollock, Measurement of atmospheric methyl bromide and bromoform, J. Geophys. Res., 93, 3745-3749, 1988.

DeFries, R.S., C.B. Field, I. Fung, C.O. Justice, S. Los, P.A. Matson, E. Matthews, H.A. Mooney, C.S. Potter, K. Prentice, P J. Sellers, J.R.G. Townshend, C.J Tucker, S.L. Ustin, and P.M. Vitousek, Mapping the land surface for global atmosphere-biosphere models: Toward continuous distributions of vegetation's functional properties, $J$. Geophys. Res., 100 (D10), 20,867-20,882, 1995.

Gan, J., S.R. Yates, M.A. Anderson, W.F. Spencer, F.F. Ernst, and M.V. Yates, Effect of soil properties on degradation and sorption of methyl bromide in soil, Chemosphere, 29 (12), 2685-2700, 1994.

Gan, J., S.R. Yates, H.D. Ohr, and J.J. Sims, Production of methyl bromide by terrestrial higher plants, Geophys. Res. Lett., 25 (19), 3595-3598, 1998.

Guenther, A.B , C. Hewitt, D. Erikson, R. Fall, C. Geron, T. Graedel, P. Harley, L. Klinger, M. Lerdau, W. McKay, T. Pierce, B. Scholes, R Steinbrecker, R. Tallamraju, J. Taylor, and P. Zimmerman, A global model of natural volatile organic compound emissions, J. Geophys. Res., 100, 8873-8892, 1995.

Hines, M.E., P.M. Crill, R.K Varner, R.W. Talbot, J.H. Shorter, C.E. Kolb, and R.C. Harriss, Rapid consumption of low concentrations of methyl bromide by soil bacteria, Appl. Environ. Micro., 64 (5), 1864-1870, 1998.

Jeffers, P.M., and N.L. Wolfe, Degradation of methyl bromide by green plants, in Fumigants, edited by J.N. Seiber, J.A. Knuteson, J.E. Woodrow, N.L. Wolfe, M.V. Yates, and S.R. Yates, pp. 53-59, 1997.

Jeffers, P.M., N.L. Wolfe, and V. Nzengung, Green plants: A terrestrial sink for atmospheric CH3Br, Geophys. Res. Lett., 25 (1), 43-46, 1998.

Kerwin, R.A., P.M. Crill, R.W. Talbot, M.E. Hines, J.H. Shorter, C.E. Kolb, and R.C. Harriss, Determination of atmospheric methyl bromide by cryotrapping-gas chromatography and application to soil kinetic studies using a dynamic dilution system, Anal. Chem., 68 (5), 899-903, 1996.

Khalil, M.A.K., R.S. Rasmussen, and R. Gunawardena, Atmospheric methyl bromide: trends and global mass balance, J. Geophys. Res., 98 (D2), 2887-2896, 1993

Lobert, J.M., J.H. Butler, S.A. Montzka, L.S. Geller, R.C. Myers, and J.W. Elkins, A net sink for atmospheric $\mathrm{CH}_{3} \mathrm{Br}$ in the East Pacific ocean, Science, 267, 1002-1005, 1995.

Mano, S., and M.O. Andreae, Emission of methyl bromide from biomass burning, Science, 263, 1255-1257, 1994.
Madigan, M.T., J.M. Martinko, and J. Parker, Brock Biology of Microorganisms, 987 pp., Prentice-Hall, Upper Saddle River, NJ, 1997.

Matthews, E., Global vegetation and land use: new high-resolution data bases for climate studies, J. Clim. Appl Meteorol., 22, 474-487, 1983.

McElroy, M.B., R.J. Salawitch, S.C. Wofsy, and J.A. Logan, Reductions of Antarctic ozone due to synergistic interactions of chlorine and bromine, Nature, 32I, 759-762, 1986.

Mellouki, A., R.K. Talukdar, A.-M. Schmolter, T. Gierczak, M J. Mills, S. Solomon, and A.R. Ravishankara, Atmospheric lifetimes and ozone depletion potentials of methyl bromide $\left(\mathrm{CH}_{3} \mathrm{Br}\right)$ and dibromomethane $\left(\mathrm{CH}_{2} \mathrm{Br}_{2}\right)$, Geophys. Res. Lett., 19, 2059-2062, 1992.

Miller, L.G., T.L. Connell, J R. Guidetti, R.S. Oremland, Bacterial oxidation of methyl bromide in fumigated agricultural soils, Appl. Environ. Micro., 63, 11, 4346-4354, 1997.

Oremland, R.S., L.G. Miller, C.W. Culbertson, T.L. Connell, and L. Jahnke, Degradation of methyl bromide by methanotrophic bacteria in cell suspensions and soils, Appl. Environ. Micro., 60, 3640-3646, 1994.

Penkett, S.A., J.H. Butler, M.J. Kurylo, C.E. Reeves, J.M. Rodriguez, H. Singh, D. Toohey, and R. Weiss, Methyl bromide, in Scientific Assessment of Ozone Depletion: 1994, World Meteorological Organization Global Ozone Monitoring Project, 1995.

Prinn, R.G., R.F. Weiss, B.R. Miller, J. Huang, F.N. Alyea, D.M. Cunnold, P B. Fraser, D.E. Hartley, and P.G. Simmons, Atmospheric trends and lifetime of trichloroethane and global average hydroxyl radical concentrations based on 1978-1994 ALE/GAGE measurements, Science, 269, 187-192, 1995

Rice, P.J., T.A Anderson, J H. Cink, and J.R. Coats, The influence of soil environmental variables on the degradation and volatility of methyl bromide in soil, Environ. Toxicol. Chem., 15, 10, 1723-1729, 1996

Serca, D., A. Guenther, L. Klinger, D. Helmig, D. Hereid, and P Zimmerman, Methyl bromide deposition to soils, Atmos. Environ., 32 (9), 1581-1586, 1998.

Shorter, J.H., C.E. Kolb, R.A. Kerwin, P.M. Crill, M.E. Hines, R.W Talbot, and R.C. Harriss, Rapid degradation of atmospheric methyl bromide in soils, Nature, 377 (6551), 717-719, 1995.

Solomon, S., M. Mills, L.E. Heidt, W.H. Pollock, and A.F. Tuck, On the evaluation of Ozone Depletion Potentials, J. Geophys. Res., 97, 825$842,1992$.

UNEP, Report of the Seventh Meeting of the Parties to the Montreal Protocol on Substances that Deplete the Ozone Layer, UNEP/OzL.Pro.7/12, Vienna, Dec. 5-7, 1995.

Wofsy, S.C., M.B. McElroy, and Y.L. Yung, The chemistry of atmospheric bromine, Geophys. Res. Lett., 2, 215-218, 1975.

World Meterological Organization,(WMO), Scientific assessment of stratospheric ozone, 1992.

Yates, S.R., J. Gan, F.F. Ernst, A. Mutzinger, and M.V. Yates, Methyl bromide emissions from a covered field: 1 . Experimental conditions and degradation in soil, J. Environ. Qual., 25 (1), 184-202, 1996.

Yates, S.R., D. Wang, F.F. Ernst, and J. Gan, Methyl bromide emissions from agricultural fields: bare-soil, deep injection, Environ. Sci. Tech. 3I (4), 1136-1143, 1997.

Yung, Y.L., J.P. Pinto, R.T. Watson, and S.P. Sander, Atmospheric bromine and ozone perturbations in the lower stratosphere, J. Atmos. Sci. 37, 339-353, 1980.

Yvon, S A., and J.H. Butler, An improved estımate of the oceanic lifetime of atmospheric $\mathrm{CH}_{3} \mathrm{Br}$, Geophys. Res. Lett., 23 (1), 53-56, 1996.

Yvon-Lewis, S.A., and J.H. Butler, The potential effect of oceanic biological degradation on the lifetime of atmospheric $\mathrm{CH}_{3} \mathrm{Br}$, Geophys. Res. Lett., 24 (10), 1227-1230, 1997.

Ruth Varner, Patrick Crill, Robert Talbot, Complex Systems Research Center, Institute for the Study of Earth, Oceans, and Space, University of New Hampshire, Durham. (ruth.varner@unh.edu)

Joanne Shorter, Center for Atmospheric and Environmental Chemistry, Aerodyne Research, Inc., Billerica, MA.

(Received September 25, 1998; revised January 6, 1999; Accepted January 14, 1999.) 